\title{
Intimate partner violence among postpartum women: associated factors
}

\author{
Violência por parceiro íntimo entre puérperas: fatores associados \\ Violencia de pareja en puérperas: factores asociados
}

\begin{abstract}
(1)
Karla Oliveira Marcacine', Erika de Sá Vieira Abuchaim', Larissa Jardini", Kelly Pereira Coca', Ana Cristina Freitas de Vilhena Abrão'

'Universidade Federal de São Paulo. São Paulo, Brazil.

"Governo do Estado de São Paulo, Euryclides de Jesus Zerbini Transplant Hospital. São Paulo, Brazil.
\end{abstract}

\author{
How to cite this article: \\ Marcacine KO, Abuchaim ESV, Jardini L, Coca KP, Abrão ACFV. Intimate partner violence among \\ postpartum women: associated factors. Rev Bras Enferm [Internet]. 2018;71(Suppl 3):1306-12. [Thematic Issue: \\ Health of woman and child] DOI: http://dx.doi.org/10.1590/0034-7167-2016-0643
}

Submission: 01-23-2017 Approval: 10-31-2017

\begin{abstract}
Objective: To identify the profile and assess the self-esteem of postpartum women, to characterize their babies and partners, and to verify the association of these characteristics with the occurrence of intimate partner violence (IPV). Method: Crosssectional study with 207 postpartum women assisted in a public clinic. Results: There was no statistic correlation among the sociodemographic variables, personal and obstetric characteristics with the occurrence of IPV. The postpartum women who showed low self-esteem presented a higher exposure risk to IPV $(p<0.01 ; \mathrm{OR}=2.01$ and $\mathrm{Cl} 95 \%$ [1.40-2.87]). The mothers of the babies that were born with low weight (less than 2,500 g) had almost twice the chances of suffering violence $(p<0.05$; $\mathrm{OR}=1.74$ and $\mathrm{Cl} 95 \%$ [1.00-3.03]). The women whose partners did not consume alcohol presented a lower probability to be exposed to IPV $(p<0.05 ; \mathrm{OR}=0.182$ and $\mathrm{Cl} 95 \%$ [0.03-0.93]). Conclusion: Women's low self-esteem, babies' inappropriate weight and consumption of alcohol by partners were correlated to the occurrence of IPV.
\end{abstract}

Descriptors: Intimate Partner Violence; Domestic Violence; Violence Against Women; Pregnancy; Postpartum Period; Obstetric Nursing.

\section{RESUMO}

Objetivo: Identificar o perfil e a autoestima de puérperas, bem como as características de seus bebês e companheiros e, verificar suas associações com a ocorrência de Violência por Parceiro Íntimo (VPI). Método: Estudo transversal, com 207 puérperas acompanhadas em um ambulatório público. Resultados: Não houve associação estatística entre as variáveis sociodemograficas, características pessoais e obstétricas com a ocorrência de VPI. As puérperas com baixa autoestima apresentaram maior risco de exposição à VPI $(p<0,01$; $\mathrm{OR}=2,01$ e IC $95 \%$ [1,40-2.87]). As mães dos bebês que nasceram com o peso inadequado (2500g) apresentaram quase duas vezes mais chances de sofrerem violência ( $p<0,05 ; \mathrm{OR}=1,74$ e IC 95\% [1.00-3.03]). As mulheres cujos companheiros não faziam uso de álcool apresentaram menos chances de exposição à VPI ( $p<0,05 ; \mathrm{OR}=0,182$ e IC 95\% [0.03-0.93]). Conclusão: A baixa autoestima das mulheres, o peso inadequado do bebê e o uso de álcool pelo companheiro estiveram associados à ocorrência de VPI.

Descritores: Violência por Parceiro Íntimo; Violência Doméstica; Violência Contra a Mulher; Gravidez; Período Pós-Parto; Enfermagem Obstétrica.

\section{RESUMEN}

Objetivo: Identificar el perfil y la autoestima de puérperas, las características de sus bebés y compañeros, y verificar sus asociaciones con la ocurrencia de Violencia de Pareja (VPI, siglas en portugués). Método: Estudio transversal, con 207 puérperas seguidas en servicio público. Resultados: No hubo asociación estadística entre variables sociodemográficas, características personales y obstétricas con la ocurrencia de VPI. Las puérperas con baja autoestima expresaron mayor riesgo de exposición a VPI ( $p<0,001 ; O R=2,01 ;$ IC 95\% [1.40-2.87]). Las madres de bebés nacidos con peso inadecuado (abajo de 2500g) presentaron casi dos veces más posibilidades de sufrir violencia $(p<0,05 ; \mathrm{OR}=0,182 ; \mathrm{IC} 95 \%$ [0.03-0.93]). Las mujeres cuyas parejas no consumían alcohol presentaron menores posibilidades de exposición a VPI ( $p<0,05$; OR=0,182 e IC 95\% [0.03-0.93]). 
Conclusión: La baja autoestima de las mujeres, el peso inadecuado del bebé y el consumo de alcohol de la pareja estuvieron asociados a la ocurrencia de VPI.

Descriptores: Violencia de Pareja; Violencia Doméstica; Violencia Contra la Mujer; Embarazo; Periodo Posparto; Enfermería Obstétrica.

\section{CORRESPONDING AUTHOR Karla Oliveira Marcacine E-mail: ka_marcacine@yahoo.com.br}

\section{INTRODUCTION}

Violence against women is widely known as a serious public health issue. The most common type of abuse, carried out by an intimate partner (intimate partner violence or IPV) ${ }^{(1)}$, is present in every period of women's lives, including pregnancy and postpartum, and may cause severe consequences to the health of mothers and people who depend on them ${ }^{(2)}$.

Recent studies performed in Vietnam and Japan identified that the prevalence of IPV during pregnancy was 35.4\% and $20.7 \%$, respectively ${ }^{(3-4)}$. In an investigation with 232 pregnant women in a public maternity hospital in the countryside of the state of São Paulo, Brazil, 15.5\% of the participants reported suffering IPV during pregnancy ${ }^{(5)}$. In the city of São Paulo, the number of affected women was higher, with a prevalence of $36.7 \%{ }^{(6)}$. The findings about the postpartum period show that abuse continues after pregnancy, with the frequency ranging from $8.3 \%$ in China $^{(7)}$ to $24.2 \%$ in Sweden ${ }^{(8)}$. In Brazil, a recent prospective cohort study showed a prevalence of $9.3 \%$ in the Northeast region and $25.6 \%{ }^{(9)}$ in São Paulo ${ }^{(6)}$. In both periods and in all the studies, the most frequent violence category was the psychological one, followed by physical and sexual ${ }^{(3-9)}$.

Violence, in all its forms, implies several consequences to maternal and neonatal health. In the pregnancy-postpartum cycle, it can be related to a late start of prenatal care, a higher probability of pre-term labor, low weight of newborns and use of healthcare resources and medication. Women can also present post-traumatic stress disorder, suicidal ideation, low self-esteem, socialization issues and abusive use of alcohol, among other drugs ${ }^{(10)}$.

Women exposed to IPV tend to depreciate themselves and present low self-confidence, difficulties to deal with challenges or adapt to a certain situation, such as pregnancy and the postpartum period, and show a higher probability to keep an abusive relationship, which increases the consequences of this exposure ${ }^{(11)}$.

Taking into account the high prevalence of IPV in the different moments of women's lives, their varied effects on maternal and neonatal health, and the need for health professionals to identify risk situations early and to handle them properly when abuse happens, the present study aimed to answer the following research question: What are the factors which contribute to the occurrence of IPV?

\section{OBJECTIVE}

To identify the profile and assess the self-esteem of women in the postpartum, as well as list the characteristics of their babies and partners, and verify if there is an association between these characteristics and the occurrence of intimate partner violence.

\section{METHOD}

\section{Ethical aspects}

The present study complied with human research rules established by the resolution 466/2012 of the Brazilian Health Council and was approved by the Research Ethics Committee of the Federal University of São Paulo.

Women who were classified as exposed to violence during the present investigation were referred to a specialized service in the institution where the study was developed and given a list of services available in the state of São Paulo which are dedicated to protecting women in this situation.

\section{Study design, setting and period}

Descriptive, cross-sectional study involving women in the postpartum assisted in the Center for Incentive and Support to Breastfeeding/Human Milk Bank.

The present investigation was carried out in a clinic that assists people through the Unified Health System (SUS, as per its acronym in Portuguese), included in the reference system by the Human Milk Bank Brazilian Network and healthcare services of the Federal University of São Paulo for prevention and resolution of problems related to breastfeeding in the south area of the city of São Paulo, state of São Paulo, Brazil. This institution was chosen because it is a space that offers a monthly follow-up for mothers and babies and commonly receives women who suffer violence, which has consequences to the health of both. It is worth to stress that health services, notably clinics and outpatient facilities, are places where healthcare professionals have a strategic position to diagnose this problem and act to help patients deal with its consequences.

The study was conducted from April 2011 to April 2012.

\section{Population or sample; inclusion and exclusion criteria}

The population investigated in the present study was postpartum women who attended nursing appointments for promoting and encouraging breastfeeding and postpartum review between April 2011 and April 2012. The sample had 207 postpartum women who met the inclusion criteria: being 18 years old or older, being capable of reading and understanding the free and informed consent form, having had a single baby in the last and only pregnancy and having children with no malformation. Women in the postpartum who did not meet the inclusion criteria and did not attend the nursing appointment between 45 to 60 days after childbirth were excluded from the sample.

\section{Study protocol}

The participants started the outpatient follow-up approximately in the seventh day after childbirth and collection of 
data about violence was carried out around 45 and 60 days after childbirth so a trust relationship between patient and researcher could develop, given that the subject of the study is intimate and delicate. Information was collected daily in the institution, in a private place with no accompanying people.

Three instruments were used to collect data: the first, designed by the authors, encompassed information about sociodemographic characteristics, life habits of the women and their partners, and personal, obstetric and neonatal information. Use of alcohol and other drugs by intimate partners was identified by this tool, whose collection procedure was based on the accounts of the interviewed participants, and was classified as social (until three times a week) and frequent (more than three times a week). The second instrument assessed women's self-esteem through the application of the Rosenberg Self-esteem Scale ${ }^{(12)}$, in the version translated and adapted to Portuguese ${ }^{(13)}$. The third instrument identified the occurrence of IPV before, during and after the pregnancy. The version used in the present study was adapted specifically for it, based on the proposed model and the variations by other authors ${ }^{(14-15)}$. This procedure was necessary because there is not a specific instrument that allows the identification of IPV in the postpartum period. The choice of this model can be justified by its comprehensive approach, which includes physical, psychological and sexual violence, and by the fact that it was created to be applied in health services and inspired in the American instrument Abuse Assessment Screen, a reference document to track violence against pregnant women.

For categorization of the self-esteem variable, scores equal to or higher than 30 were associated with a high self-esteem and scores lower than 30 indicated low self-esteem ${ }^{(12)}$.

As for the identification of IPV, the authors considered the presence of at least one positive answer to the questions about psychological, physical and sexual IPV before, during and after pregnancy. This parameter was defined as the dependent variable in the present study.

\section{Result analysis and statistics}

Data were organized in Microsoft Excel software worksheets after double typing, which allowed the validation of the typed information, reduced the chances of typos and guaranteed reliability in data compilation. Analysis was carried out with the use of the Statistical Analysis System SAS ${ }^{\circledast} 9.0$ software. Sample characterization was performed with the application of descriptive statistics. Chi-square and Fisher's exact tests were run to verify the association among category variables, and continuous variables were evaluated with MannWhitney and Student's t tests. The quantification of this association was assessed through logistic regression models; gross odds ratios (OR) were calculated, with respective confidence intervals $(\mathrm{Cl})$ of $95 \%$. In all statistical analyses, p values lower than 0.05 were considered significant.

\section{RESULTS}

The sample of the present study was made up of young women with an average age of 29 years, predominantly Catholic
(50.2\%), who finished high school $(67.1 \%)$, single $(62.3 \%)$, who lived with their partners $(83.6 \%)$ and who did not work $(54.6 \%)$. More than half of the participants (56.5\%) reported a monthly income ranging from one to three minimum wages (the reference value was the minimum wage adopted in 2012, $\mathrm{R} \$$ 622.00) and declared that their partners were the main providers in the family $(50.2 \%)$. More than half the women $(55.6 \%)$ had underlying diseases, among which systemic arterial pressure and heart illnesses were the most common. Most participants did not smoke $(92.3 \%)$, did not consume alcohol (95.2\%) or illicit drugs $(97.1 \%)$.

The partners of the women in the sample were, on average, 31 years old, finished high school (58.0\%), had a formal employment relationship $(61.8 \%)$, did not smoke $(68.6 \%)$, drank alcohol in social situations (50.6\%) and did not use illicit drugs $(83.6 \%)$.

As for obstetric characteristics, most women were multiparous $(59.9 \%), 30.4 \%$ reported a previous miscarriage and $70.5 \%$ declared that the recent pregnancy was desired. Regarding prenatal care, $73.9 \%$ started regular check-ups in the first semester of pregnancy and $90.8 \%$ attended six or more appointments. Most participants (73.4\%) reported at least one complication during pregnancy, $8.2 \%$ presented a complication during childbirth and $80.2 \%$ during the postpartum. Normal childbirth was prevalent in the studied population (55.8\%).

The questions about newborns revealed that most of them were born full-term (87.9\%), were males (50.2\%) and presented an Apgar score between 8 and 10 (89.9\%) in the first minute of life and between 7 and 10 (99.5\%) in the fifth minute of life. The birth weight was, on average, 3.101 kilograms and $39.1 \%$ presented at least one type of complication during birth.

Analysis of prevalence of violence cases among the participants showed that $51.2 \%$ suffered IPV at some point; $49.3 \%$ reported psychological, $18.4 \%$ physical and $4.8 \%$ sexual abuse. Approximately one third of the sample (36.7\%) mentioned that the IPV happened during pregnancy and $25.6 \%$ declared that aggression persisted after childbirth. In both periods, psychological violence was the most common $(32.9 \%$ during pregnancy and $25.1 \%$ after childbirth), followed by physical (14\% during pregnancy and $4.3 \%$ after childbirth) and sexual (3.9\% during pregnancy and $0.5 \%$ after childbirth).

\section{Factors associated with intimate partner violence}

Table 1 displays the association between IPV and personal and obstetric characteristics of the studied women. Data analysis showed no statistical significance in the results.

Another aspect examined in the study was the relationship between the self-esteem of the women in the sample and the occurrence of IPV. The average score obtained in the self-esteem assessment was $23.44 \pm 2.93$ and only one participant reached a score higher than 30 . The evaluation of the association between self-esteem and types of violence revealed that women with low self-esteem (total score lower than 30) presented a higher IPV exposure risk $(\mathrm{p}<0.01$; OR $=2.01$ and Cl 95\% [1.40-2.87]), as shown in Table 2. 
Table 1 - Predictive model of personal and obstetric characteristics associated with intimate partner violence, São Paulo, São Paulo, Brazil, 2012

\begin{tabular}{|c|c|c|c|c|c|c|}
\hline Characteristics & IPV & $\%$ & $p$ value $\neq$ & Gross odds ratio (Cl95\%) & $p$ value $\neq \neq$ & $\begin{array}{c}\text { Adjusted odds ratio } \\
\text { (Cl95\%) }\end{array}$ \\
\hline \multicolumn{7}{|l|}{ Underlying diseases } \\
\hline Yes & 35 & 55.6 & \multirow[t]{2}{*}{0.40} & $1.285(0.709-2.329)$ & 0.45 & $0.773(0.39-1.530)$ \\
\hline No & 71 & 49.3 & & 1.000 & - & 1.000 \\
\hline \multicolumn{7}{|c|}{ Systemic arterial hypertension (SAH) } \\
\hline Yes & 7 & 50.0 & \multirow[t]{2}{*}{$0.99+$} & $0.949(0.321-2.821)$ & 0.69 & \multirow{2}{*}{$\begin{array}{c}1.292(0.370-4.480) \\
1.000\end{array}$} \\
\hline No & 99 & 51.3 & & 1.000 & - & \\
\hline \multicolumn{7}{|l|}{ Miscarriage } \\
\hline Yes & 35 & 55.6 & \multirow[t]{2}{*}{0.40} & $1.285(0.709-2.329)$ & 0.26 & \multirow{2}{*}{$\begin{array}{c}0.703(0.381-1.310) \\
1.000\end{array}$} \\
\hline No & 71 & 49.3 & & 1.000 & - & \\
\hline \multicolumn{7}{|l|}{ Start of prenatal care } \\
\hline 1 st trimester & 75 & 49.0 & \multirow{3}{*}{$0.32+$} & $0.687(0.402-0.972)$ & 0.79 & $1.269(0.210-7.820)$ \\
\hline 2nd trimester & 28 & 58.3 & & $0.962(0.146-1.774)$ & 0.27 & $1.502(0.720-3.117)$ \\
\hline 3rd trimester & 3 & 50.0 & & 1.000 & - & 1.000 \\
\hline \multicolumn{7}{|c|}{ Number of prenatal appointments } \\
\hline$\geq 6$ & 95 & 50.5 & \multirow[t]{2}{*}{0.68} & $1.224(0.463-3.237)$ & 0.77 & \multirow{2}{*}{$\begin{array}{c}1.177(0.388-3.68) \\
1.000\end{array}$} \\
\hline$<6$ & 10 & 55.6 & & 1.000 & - & \\
\hline \multicolumn{7}{|c|}{ Complications during pregnancy } \\
\hline Yes & 82 & 53.9 & \multirow[t]{2}{*}{0.19} & $0.661(0.355-1.230)$ & 0.18 & \multirow{2}{*}{$\begin{array}{c}0.641(0.383-3.368) \\
1.000\end{array}$} \\
\hline No & 24 & 43.6 & & 1.000 & - & \\
\hline \multicolumn{7}{|l|}{ Last childbirth } \\
\hline Vaginal & 53 & 55.8 & \multirow[t]{3}{*}{0.38} & $1.829(1.272-2.344)$ & 0.33 & $0.618(0.230-1.630)$ \\
\hline Cesarean section & 44 & 48.9 & & $1.319(1.010-1.629)$ & 0.40 & $0.772(0.420-1.410)$ \\
\hline Forceps & 9 & 40.9 & & 1.000 & - & 1.000 \\
\hline \multicolumn{7}{|l|}{ Complications during childbirth } \\
\hline Yes & 9 & 52.9 & \multirow[t]{2}{*}{0.88} & $0.927(0.343-2.505)$ & 0.89 & \multirow{2}{*}{$\begin{array}{c}0.929(0.422-2.682) \\
1.000\end{array}$} \\
\hline No & 97 & 51.1 & & 1.000 & - & \\
\hline \multicolumn{7}{|l|}{ Complications after childbirth } \\
\hline Yes & 83 & 50.0 & \multirow[t]{2}{*}{0.48} & \multirow[t]{2}{*}{$1.278(0.642-2.242)$} & 0.69 & \multirow{2}{*}{$\begin{array}{c}1.155(0.570-2.360) \\
1.000\end{array}$} \\
\hline No & 23 & 56.1 & & & - & \\
\hline
\end{tabular}

Note: IPV = intimate partner violence; $\ddagger=$ Chi-square test; $\neq \neq=G L M ; \dagger=$ linear trend chi-square test.

Table 2 - Predictive model of the self-esteem of the studied postpartum women associated with intimate partner violence, São Paulo, São Paulo, Brazil, 2012

\begin{tabular}{ccccc}
\hline Characteristics & IPV & \% & $\boldsymbol{p}$ value $\neq \neq$ & Gross odds ratio (Cl95\%) \\
\hline Self-esteem versus IPV & & & & \\
Total score $<30$ & 105 & $50.7 \%$ & 0.0001 & $2.0103(1.4036-2.8792)$ \\
Total score $\geq 30$ & 1 & $0.4 \%$ & - & 1.000 \\
\hline
\end{tabular}

Note: IPV = intimate partner violence; キ‡ GLM.
As for the characteristics of newborns, it was observed that women whose babies were born with a weight lower than $2,500 \mathrm{~g}$ presented almost twice the chances of suffering violence $(p<0.05$; $\mathrm{OR}=1.74$ and $\mathrm{Cl} 95 \%$ [1.003.03]). The variables gender and Apgar score after birth did not show statistical significance.

Table 3 - Predictive model of the association between intimate violence partner and sociodemographic characteristics of women and habits of life of their partners, São Paulo, São Paulo, Brazil, 2012

\begin{tabular}{|c|c|c|c|c|c|c|}
\hline Characteristics & IPV & $\%$ & $p$ value $\neq$ & Gross odds ratio (CI95\%) & $p$ value $\neq \ddagger$ & Adjusted odds ratio (CI95\%) \\
\hline \multicolumn{7}{|l|}{ Use of alcohol by the partner } \\
\hline Does not use it & 36 & 42.9 & $0.03+$ & $0.190(0.01-0.460)$ & 0.04 & $0.182(0.035-0.935)$ \\
\hline Uses it socially & 45 & 50.6 & & $0.260(0.01-0.630)$ & 0.10 & $0.256(0.050-1.312)$ \\
\hline Uses it frequently & 8 & 80.0 & & 1.000 & - & 1.000 \\
\hline
\end{tabular}




\begin{tabular}{|c|c|c|c|c|c|c|}
\hline Characteristics & IPV & $\%$ & $p$ value $\neq$ & Gross odds ratio (Cl95\%) & $p$ value $\neq \neq$ & Adjusted odds ratio (Cl95\%) \\
\hline \multicolumn{7}{|l|}{ Family income } \\
\hline Until 1 minimum wage & 15 & 62.5 & $0.008+$ & $3.666(3.190-4.558)$ & 0.20 & $2.671(0.586-12.171)$ \\
\hline 1 to 3 minimum wages & 66 & 56.4 & & $2.847(2.090-3.219)$ & 0.18 & $2.200(0.701-6.906)$ \\
\hline 3 to 5 minimum wages & 20 & 40.0 & & $1.46(0.705-2.227)$ & 0.77 & $1.203(0.349-4.150)$ \\
\hline More than 5 minimum wages & 5 & 31.3 & & 1.000 & - & 1.000 \\
\hline \multicolumn{7}{|l|}{ Both are providers } \\
\hline Yes & 80 & 55.9 & 0.04 & $1.850(1.020-3.337)$ & 0.35 & $0.748(0.385-1.451)$ \\
\hline No & 26 & 40.6 & & 1.000 & - & 1.000 \\
\hline \multicolumn{7}{|l|}{ Other providers } \\
\hline Yes & 84 & 47.5 & 0.01 & $0.382(0.071-0.586)$ & 0.27 & $1.995(0.624-6.377)$ \\
\hline No & 22 & 73.3 & & 1.000 & - & 1.000 \\
\hline
\end{tabular}

Note: IPV = intimate partner violence; $\ddagger=$ Chi-square test; $\neq \ddagger=G L M ; \dagger=$ linear trend chi-square test.

Table 3 presents the association between IPV and sociodemographic characteristics of the studied women and habits of life of their partners.

Data analysis demonstrated that women whose partners did not consume alcohol had a smaller probability to suffer abuse $(p<0.05 ; \mathrm{OR}=0.18$ and $\mathrm{Cl} 95 \%$ [0.03-0.93]).

\section{DISCUSSION}

The present study allowed to identify the profile and assess the self-esteem of postpartum women, find out the characteristics of their babies and partners and verify the association of these characteristics with the occurrence of IPV.

Analysis of personal and obstetric characteristics of the interviewed women found that they did not present a significant association with the occurrence of IPV. Contrarily to this finding, other studies indicated that women exposed to physical violence had a more proper and qualified prenatal care in comparison with those who did not suffer abuse $\mathrm{e}^{(16-17)}$. The quality of prenatal care was not evaluated in the present study, but the results showed that most women started the follow-up appointments in the advocated period and had at least six appointments.

Regarding obstetric repercussions, such as complications during pregnancy, childbirth and postpartum, no statistically significant associations with the dependent variable were found. Investigations show that women who suffer abuse before and during pregnancy may experience more complications, among which sexually transmitted diseases, hypertension, vaginal bleeding, diabetes, urinary tract infection ${ }^{(18-19)}$ and postpartum depression ${ }^{(20)}$ stand out.

Analysis of the association between IPV and the level of selfesteem assessed through the Rosenberg scale ${ }^{(12)}$ revealed that women with low self-esteem presented a risk twice higher to be exposed to IPV. This outcome corroborates the findings of a study carried out in Spain, which reported that gender violence was the determining cause for women's low self-esteem and was frequently associated with psychopathological symptoms, such as somatization, compulsion, depression, phobia, and anxiety ${ }^{(21)}$.

Some investigations reported average scores between 26.7(22) and 27.5 points $^{(11)}$, which are considered low according to the classification, but higher than the values found in the present study.

It is noteworthy that this scale was not designed specifically to be applied to postpartum women and that this moment of life is complex, with intense physical, emotional and sociocultural changes, which are closely related to the way women see and value themselves, a fact that can help explain the results found in the present study.

The results allow to infer that basic human needs are intertwined and well-being depends on safety. The safer human beings feel in the environment where they live, the higher the self-esteem, which will be enhanced through trust and respect. A situation of violence, together with intense changes experienced during the postpartum period, can make women feel uneasy in their social environment, reinforcing negative feelings grounded on insecurity and distrust.

Consequently, satisfactory and unsatisfactory connotations of self-esteem depend on positive and negative experiences, mainly the ones related to affection, love, valorization and success or failure experienced by people over time and in different phases of their lives.

The relationship between self-esteem and IPV is still little explored in recent literature and no studies that address this association during pregnancy and postpartum were found.

As for the information regarding newborns, women whose babies were born with low weight $(<2,500 \mathrm{~g})$ presented twice more chances to be IPV victims, a finding that corroborates the results of other studies ${ }^{(23-24)}$. A systematic review and metanalysis carried out in 2004 in the United States, Norway, and Australia demonstrated that women exposed to physical, sexual or psychological abuse during pregnancy had 1.4 more chances to give birth to a low-weight baby ${ }^{(24)}$.

Despite the evidence frequently associated with physical violence during pregnancy, this relationship is not a consensus in recent literature. An investigation performed almost two decades ago in Norway did not show a positive correlation, but more recent studies developed in Vietnam ${ }^{(3)}$, East Timor ${ }^{(25)}$ and the South region of Brazil(26) reported this association.

Different methodologies and the level of economic and sociocultural development of the countries where research is performed can contribute to making this association questionable. New studies will be able to confirm this relationship and reveal other associations of IPV with fetal development and neonatal health.

Regarding the habits of life of the women's partners, the participants whose partners did not consume alcohol had a 
smaller probability to be abused, a result that is in agreement with other studies ${ }^{(14,16)}$.

It is known that alcohol reduces inhibition, judgment and the capacity to interpret signs, which increases the probability of aggression episodes. Nevertheless, the association between the consumption of alcohol and IPV is still a controversial subject in literature. A recent study carried out in the Northeast region of Brazil with 1,057 postpartum women did not show a statistically significant correlation between the use of alcohol by partners and the occurrence of IPV after childbirth ${ }^{(9)}$. Investigations have been demonstrating that this relationship depends on the different ways to assess the consumption of alcohol, individual characteristics of the partners, circumstantial variables and factors inherent to the couple's relationship ${ }^{(27-28)}$. New studies may help elucidate this topic.

\section{Study limitations}

The main limitation of the present study is the analysis of women from a single healthcare service, with local specificities. The authors suggest more comprehensive, follow-up investigations to broaden the knowledge about the subject.

\section{Contributions to the fields of nursing, and health or public policies}

The present study listed maternal and neonatal factors associated with IPV, contributing to the early identification of risk situations and the planning and implementation of local public policies, given that this phenomenon is influenced by sociocultural contexts. Information about these factors is still limited, especially in developing countries.

Discussion on this and other questions must be expanded to allow the training of professionals, the establishment of collaboration with other services, the knowledge of references in legal, police, social and psychological scopes, in addition to the knowledge of informal support networks and nongovernmental organizations, to guarantee proper and continuous care.

\section{CONCLUSION}

The present study showed that women with low self-esteem whose babies presented low weight at birth and partners consumed alcohol were more likely to be exposed to IPV.

Intimate partner violence brings important consequences to women and children, which reinforces the need to sensitize professionals that work in different health settings, so they can identify abuse in early stages and plan a more comprehensive and supportive care to these women and families.

\section{FUNDING}

The present study was sponsored by the Coordination for Improvement of Higher Education Personnel.

\section{REFERENCES}

1. World Health Organization - WHO multi-country study on women's health and domestic violence against women: summary report of initial results on prevalence, health outcomes and women's responses. Geneva; 2005 [cited 2016 Dec 7]. Available from: http://www.who.int/gender/violence/who_multicountry_study/summary_report/summary_report_English2.pdf

2. Rodrigues DP, Gomes-Sponholz FA, Stefanelo J, Nakano AMS, Monteiro JCS. Intimate partner violence against pregnant women: study about the repercussions on the obstetric and neonatal results. Rev Esc Enferm USP [Internet]. 2014 [cited 2016 Dec 7];48(2):206-12. Available from: http://www.scielo.br/pdf/reeusp/v48n2/0080-6234-reeusp-48-02-206.pdf

3. Hoang TN, Van TN, Gammeltoft T, Meyrowitsch DW, Thuy HNT, Rasch V. Association between intimate partner violence during pregnancy and adverse pregnancy outcomes in vietnam: a prospective cohort study. PLoS One [Internet]. 2016 [cited 2016 Dec 7];11(9):1-14. Available from: http://journals.plos.org/plosone/article/file?id=10.1371/journal.pone.0162844\&type=printable

4. Telles LEB, Barros AJ, Moreira CG, Almeida MR, Telles MB, Day VP. Intimate partner violence during pregnancy: case report of a forensic psychiatric evaluation. Rev Bras Psiquiatr [Internet]. 2016 [cited 2016 Dec 7];38(1):87-8. Available from: http://www. scielo.br/pdf/rbp/v38n1/1516-4446-rbp-38-01-00087.pdf

5. Lettiere A, Nakano AMS, Bittar DB. Violence against women and its implications for maternal and child health. Acta Paul Enferm [Internet]. 2012 [cited 2016 Dec 7];25(4):524-9. Available from: http://www.scielo.br/pdf/ape/v25n4/en_07.pdf

6. Marcacine KO, Abuchaim ESV, Abrahão AR, Michelone CSL, Abrão ACFV. Prevalence of intimate partner violence reported by puerperal women. Acta Paul Enferm [Internet]. 2013 [cited 2016 Dec 7];26(4):395-400. Available from: http://www.scielo.br/pdf/ ape/v26n4/en_v26n4a15.pdf

7. Guo SF, Wu JL, Qu CY, Yan RY. Domestic abuse on women in China before, during, and after pregnancy. Chin Med J (Engl). 2004;117(3):331-6.

8. Hedin LW. Postpartum, also a risk period for domestic violence. Eur J Obstet Gynecol Reprod Biol. 2000;89(1):41-5.

9. Silva EP, Valongueiro S, Araújo TVB, Ludermir AB. Incidence and risk factors for intimate partner violence during the postpartum period. Rev Saude Publica [Internet]. 2015 [cited 2016 Dec 7];49:6. Available from: http://www.scielo.br/pdf/rsp/v49/0034-8910rsp-S0034-89102015049005432.pdf

10. Huth-Bocks AC, Levendosky AA, Bogat GA. The effects of domestic violence during pregnancy on maternal and infant health. Violence Vict [Internet]. 2002[cited 2016 Dec 7];17(2):169-85. Available from: https://www.ncbi.nlm.nih.gov/pubmed/12033553 
11. Amor P, Echeburúa P, Corral P, Sarasúa B, Zubizarreta I. Maltrato físico y maltrato psicológico en mujeres víctimas de violencia en el hogar: un estudio comparativo. Int J Clin Health Psychol [Internet]. 2001 [cited 2016 Dec 7];2:227-246. Available from: http://e-spacio.uned.es/fez/eserv/bibliuned:Psicopat-2001-1AE8F504-FC17-A968-D84A-1BC8F41846E5/PDF

12. Rosenberg M. Society and the adolescent self-image. Princeton: Princeton University Press; 1989. 326p.

13. Hutz CS, Zanon C. Revision of the adaptation, validation, and normatization of the Roserberg self-esteem scale. Aval Psicol [Internet]. 2011[cited 2016 Dec 7];10(1):41-9. Available from: http://pepsic.bvsalud.org/pdf/avp/v10n1/v10n1a05.pdf

14. Lipsky S, Caetano R, Field CA, Larkin GL. Is there a relationship between victim and partner alcohol use during an intimate partner violence event? findings from an urban emergency department study of abused women. J Stud Alcohol [Internet]. 2005[cited 2016 Dec 7];66(3):407-12. Available from: http://www.jsad.com/doi/10.15288/jsa.2005.66.407

15. Schraiber LB, D'Oliveira AFP, França-Jr I, Pinho AA. Violência contra a mulher: estudo em uma unidade de atenção primária à saúde. Rev Saúde Pública [Internet]. 2002 [cited 2016 Dec 7];36(4):470-7. Available from: http://www.scielo.br/pdf/rsp/v36n4/11766.pdf

16. Moraes $\mathrm{CL}$, Arana FDN, Reichenheim ME. Physical intimate partner violence during gestation as a risk factor for low quality of prenatal care. Rev Saúde Pública [Internet]. 2010 [cited 2016 Dec 7];44(4):667-76. Available from: http://www.scielo.br/pdf/rsp/ v44n4/en_10.pdf

17. Viellas EF, Gama SGN, Carvalho ML, Pinto LW. Factors associated with physical aggression in pregnant women and adverse outcomes for the newborn. J Pediatr [Internet]. 2013 [cited 2016 Dec 7];89(1):83-90. Available from: http://www.scielo.br/pdf/ jped/v89n1/en_v89n1a13.pdf

18. Silverman JG, Decker MR, Reed E, Raj A. Intimate partner violence victimization prior to and during pregnancy among women residing in 26 U.S. states: associations with maternal and neonatal health. Am J Obstet Gynecol [Internet]. 2006 [cited 2016 Dec 7];195(1):140-8. Available from: http://linkinghub.elsevier.com/retrieve/pii/S0002-9378(05)02751-1

19. Finnbogadottir H, Dejin-Karlsson E, Dykes AK. A multi-centre cohort study shows no association between experienced violence and labour dystocia in nulliparous women at term. BMC Pregnancy Childbirth [Internet]. 2011 [cited 2016 Dec 7];11:14. Available from: http://bmcpregnancychildbirth.biomedcentral.com/articles/10.1186/1471-2393-11-14

20. Ludermir AB, Lewis G, Valongueiro SA, Araujo TVB, Araya R. Violence against women by their intimate partner during pregnancy and postnatal depression: a prospective cohort study. Lancet [Internet]. 2010[cited 2016 Dec 7];376(9744):903-10. Available from: http://linkinghub.elsevier.com/retrieve/pii/S0140-6736(10)60887-2

21. Garaigordobil M, Pérez J, Mozaz M. Self-concept, self-esteem and psychopathological symptoms. Psicothema [Internet]. 2008 [cited 2016 Dec 7];20(1):114-23. Available from: http://www.psicothema.com/pdf/3436.pdf

22. Oliver MS, Llanos LTL, Vallejo RQ, Heández AI. Violencia de género y autoestima: efectividad de una intervención grupal. Apunt Psicol [Internet]. 2014 [cited 2016 Dec 7];32(1):57-63. Available from: http://www.apuntesdepsicologia.es/index.php/revista/ article/view/487/393

23. Viellas EF, Gama SGN, Carvalho ML, Pinto LW. Factors associated with physical aggression in pregnant women and adverse outcomes for the newborn. J Pediatr [Internet]. 2013 [cited 2016 Dec 7];89(1):83-90. Available from: http://www.scielo.br/pdf/ jped/v89n1/en_v89n1a13.pdf

24. Ludermir AB, Lewis G, Valongueiro SA, Araujo TVB, Araya R. Violence against women by their intimate partner during pregnancy and postnatal depression: a prospective cohort study. Lancet [Internet]. 2010[cited 2016 Dec 7];376(9744):903-10. Available from: http://linkinghub.elsevier.com/retrieve/pii/S0140-6736(10)60887-2

25. Habtamu D, Dabere N, Ketema G. A case-control study on intimate partner violence during pregnancy and low birth weight, Southeast Ethiopia. Obstet Gynecol Int [Internet]. 2015 [cited 2016 Dec 7].2015:394875 Available from: https://www.hindawi. com/journals/ogi/2015/394875/

26. Murphy CC, Schei B, Myhr TL, Du Mont J. Abuse: a risk factor for low birth weight? a systematic review and meta-analysis. Can Med Assoc J[Internet]. 2001 [cited 2016 Dec 7];164(11):1567-72. Available from: https://www.ncbi.nlm.nih.gov/pmc/articles/ PMC81110/

27. Taft AJ, Powell RL, Watson LF. The impact of violence against women on reproductive health and child mortality in TimorLeste. Aust N Z J Public Health [Internet]. 2015[cited 2016 Dec 7];39(2):177-81. Available from: https://www.ncbi.nlm.nih.gov/ pubmed/25715972

28. Oliver MS, Llanos LTL, Vallejo RQ, Heández AI. Violencia de género y autoestima: efectividad de una intervención grupal. Apunt Psicol [Internet]. 2014 [cited 2016 Dec 7];32(1):57-63. Available from: http://www.apuntesdepsicologia.es/index.php/revista/ article/view/487/393 